\section{Arbuscular Mycorrhiza and Plant Growth-promoting Bacteria Alleviate Drought Stress in Walnut}

\author{
Azadeh Behrooz and Kourosh Vahdati ${ }^{1}$ \\ Department of Horticulture, College of Aburaihan, University of Tehran, \\ Pakdasht, Iran
}

Farhad Rejali

Soil and Water Research Institute, Agricultural Research Education and Extension Organization (AREEO), Karaj, Iran.

\section{Mahmoud Lotfi and Saadat Sarikhani \\ Department of Horticulture, College of Aburaihan, University of Tehran, Pakdasht, Iran}

\section{Charles Leslie \\ Department of Plant Sciences, University of California, Davis, One Shields Avenue, Davis, CA 95616}

Additional index word. Azotobacter chroococcum, Glomus etunicatum, nutrient acquisition, peroxidase activity, proline, symbiotic bacteria

\begin{abstract}
Drought stress is one of the main constraints limiting worldwide crop production. Arbuscular mycorrhizae (AM) and plant growth-promoting bacteria (PGPB) such as Azotobacter chroococcum and Azospirillium lipofrum have been shown to alleviate drought stress effects. Therefore, the interaction effect of AM fungi [Glomus mosseae, G. etunicatum, and a mix of these (G. mix), and PGPB bacteria (Azotobacter chroococcum + Azospirillium lipofrum)] was investigated in 1-year-old walnut seedlings (cv. Chandler) under normal and drought stress conditions. Drought stress reduced growth (plant height, root length, number of leaves, and fresh weight) and leaf nutrient content ( $N$, $P$, and $Z n$ ) significantly of walnut plants. In contrast, proline, total soluble sugar, starch peroxidase enzyme activity, and total phenolic content of walnut leaves increased under this stress. Application of fungi or bacteria, and especially their simultaneous use, alleviated the negative effects of drought stress on walnut seedlings. AM fungi and PGPB increased significantly the content of some metabolites, including total phenolic content, proline level, peroxidase activity, total soluble sugar, and starch content as well as peroxidase enzyme activity. This led to an increase in walnut plant growth under the drought stress condition. Among AM fungi, G. etunicatum was more effective in reducing drought stress symptoms than either $G$. mosseae or the $G$. mix of fungi. In conclusion, use of $G$. etunicatum, along with PGPB, can reduce negative effects of drought stress on walnut seedlings.
\end{abstract}

Walnuts (Juglans regia L.) are the third most important nut crop in terms of world trade and the second most important nut crop (after cashews) in the world in terms of production (Food and Agriculture Organization, 2017). This nut tree is cultivated around the world for its highly nutritious kernels and resilient wood (Vahdati et al., 2014). Also, walnuts are an important food source in some Middle Eastern countries (Lotfi et al., 2019).

Received for publication 14 Feb. 2019. Accepted for publication 4 Mar. 2019.

We thank the University of Tehran, Center of Excellence for Walnut Improvement and Technology, and Iran National Science Foundation for their support.

We acknowledge Raheleh Jahanbani and Mahmoud Reza Roozban for prereviewing the manuscript.

${ }^{1}$ Corresponding author. E-mail: kvahdati@ut.ac.ir. varieties enable avoidance, escape, or tolerance of drought stress (Basu et al., 2016). However, increasing drought tolerance by breeding is very complicated (Sahebi et al., 2018). In addition to exploiting genetic potential, effects of drought stress can be ameliorated by agronomic practices (Farooq et al., 2009), including use of soil microorganisms that are symbiotic with plants. These organisms can fix atmospheric N, solubilize $\mathrm{P}$, stimulate plant growth by synthesizing growth-promoting substances, enhance decomposition of plant residues to release vital nutrients, and increase humic content of soils, providing an environmentally benign approach to nutrient management and improved ecosystem function $(\mathrm{Wu}$ et al., 2005). AM fungi are widespread microorganisms that have symbiotic associations with the roots of $\approx 80 \%$ of terrestrial plant species (Evelin et al., 2009). AM fungi promote plant growth and improve plant establishment by increasing nutrient and water relations. In particular, they can increase uptake of immobile nutrients, especially P (Manjunath and Habte, 1988). In addition, they improve soil structure and plant tolerance to biotic and abiotic stresses (Evelin et al., 2009; Habte et al., 2001).

Several studies have reported that AM fungi are able to alleviate salinity and drought stress through increased efficiency of water and nutrient absorption and water translocation (Evelin et al., 2009; Pickles and Simard, 2017; Wu et al., 2013; Yang et al., 2014). Enhancement of drought tolerance by AM fungi is a complex process involving a combination of physiologic, physical, nutritional, and cellular effects (Wu et al., 2013). Increased water uptake and transfer to plants occurs through fungal hyphae. Water and nutrients that are absorbed by AM hyphae move by apoplastic fluid flow into host plant roots (Barzana et al., 2012). AM fungi also can increase the (osmotic potential) $\psi_{\mathrm{S}}$ of plant roots by contributing to the accumulation of osmoticants, including proline, free amino acids, and sugars (Kubikova et al., 2001; Yooyongwech et al., 2013). AM fungi can also change plant root system architectures in favor of increased water absorption under drought stress conditions by increasing the number of lateral roots, root branching density, root diameter, root length, and root mortality ( $\mathrm{Wu}$ et al., 2012, 2013).

In addition to AM fungi, PGPB can also play important roles in host plant health and alleviation of drought stress. PGPB can promote plant growth and yield under both normal and stress conditions (Viscardi et al., 2016). Azotobacter chroococcum is an $\mathrm{N}$-fixing PGPB that has been shown to promote plant growth under a variety of soil types and climatic conditions, and the bacterium $A$. chroococcum is able to ameliorate negative effects of abiotic stresses (RomeroPerdomo et al., 2017). Viscardi et al. (2016) reported that some strains of $A$. chroococcum could alleviate drought stress effects in 
tomato plants. Another PGPB, Azospirillium lipofrum, mitigates negative impacts of abiotic stress by fixing $\mathrm{N}$, producing auxins, and increasing root growth (Arzanesh et al., 2011; Ramos et al., 2002).

Most studies on the effects of AM fungi and PGPB on drought stress have been limited to agronomic crops, especially cereals. Only a few have investigated the impact of AM and PGPB on fruit crops under normal and stress conditions. Because of the increased severity of drought stress in recent years, and the positive effects of AM fungi and PGPB on alleviation of drought stress in other plants, this study was conducted to examine the effect of AM fungi and PGPB (Azotobacter chroococcum and Azospirillium lipofrum) on the amelioration of negative effects of drought in walnut trees, with the aim of increasing growth and production in walnut orchards.

\section{Materials and Methods}

Plant materials and treatments. The plants used were 1-year-old walnut seedlings of Juglans regia cv. Chandler planted in $10-\mathrm{kg}$ plastic pots containing sterilized sandy loamy soil (electrical conductivity, 0.62 $\mathrm{dS} \cdot \mathrm{m}^{-1}$; pH, 7; K, 2042 ppm; P, 4.94 ppm; $\mathrm{N}, 500 \mathrm{ppm}$ ). For evaluating interaction effects of AM fungi and PGPB on walnut seedlings under stress and normal conditions, this experiment was conducted as a factorial completely randomized design with three factors (AM fungi, PGPB, and drought stress) and four replications. AM fungi treatments included Glomus mosseae, G. etunicatum, a mix of both (G. mix), and a control. The PGPB treatment consisted of either a mix of Azotobacter chroococcum and Azospirillium lipofrum or a control. Two water conditions (normal or drought stress) were used. Before planting the walnut seedlings, the soil was inoculated with $10 \mathrm{~g}$ AM fungi (80 active propagules $/ \mathrm{g})$ or $10 \mathrm{~mL}\left(10^{8} \mathrm{mix}\right.$ of bacteria/ $\mathrm{mL})$ PGPB, provided by the Soil and Water Research Institute of Iran.

All plants were placed in a greenhouse with the same conditions and management. Five months after inoculation of AM fungal and PGPB treatments, drought stress was applied by withholding water for $20 \mathrm{~d}$. During the experiment, the soil of pots was sampled daily to determine the soil water potential and soil moisture content to determine the water retention curve. Also, all studied traits were measured at the beginning and end of the drought stress period.

Plant growth characteristics. Plant height and root length were measured by ruler. Plant fresh weight was measured by digital scale. The percentage of leaf abscission was calculated by dividing the number of abscised leaves by the total number of leaves. These data were recorded $1,4,8,12$, and $20 \mathrm{~d}$ after applying drought stress.

Estimation of total $N, P$, and $Z n$. Total N was determined using the Kjeldahl method (Bradstreet, 1954). P and $\mathrm{Zn}$ concentrations were determined by inductively coupled plasma-mass spectrometry (Masson et al., 2010).

Physiologic and biochemical characteristics. Chlorophyll, proline, total soluble sugar, starch, and total phenolic content, and peroxidase enzyme activity were determined. The relative amount of chlorophyll was measured using an SPAD 502 (Konica Minolta, Inc., Japan). Total soluble sugar and starch contents of leaves were extracted with $80 \%$ hot ethanol and determined by the phenol-sulfuric acid method according to Chow and Landhausser (2004). Total phenolic content of leaves was determined using Folin-Ciocalteu reagent (Blainski et al., 2013). Free proline content in walnut leaves was determined using the method of Bates et al. (1973). For this purpose, a 0.1-g leaf sample was homogenized in $10 \mathrm{~mL}$ sulfosalicylic acid (3\%). After filtration, $2 \mathrm{~mL}$ ninhydrin and $2 \mathrm{~mL}$ glacial acetic acid were added to $2 \mathrm{~mL}$ filtrate and incubated for $1 \mathrm{~h}$ at $100{ }^{\circ} \mathrm{C}$. Then, $4 \mathrm{~mL}$ toluene was added to the reaction mixture and vortexed for $15-20 \mathrm{~s}$. The chromophore containing toluene was measured at $520 \mathrm{~nm}$ using a spectrophotometer (Lamda 25; Perkin Elmer, Waltham, MA). The proline concentration was determined according to a standard curve.

Peroxidase activity of leaf samples was determined using the method of Kar and Mishra (1976). For this purpose, $1 \mathrm{~g}$ fresh materials was homogenized in cold phosphate buffer ( $0.05 \mathrm{M}$ at $\mathrm{pH} 6.5)$. The homogenate was centrifuged at $10,000 g_{n}$ for 10 min. The clear supernatant was considered the enzyme source. Then, $5 \mathrm{~mL}$ of the assay mixture (including $1 \mathrm{~mL}$ of the $20 \times$ diluted enzyme extract, $125 \mu \mathrm{M}$ phosphate buffer, $50 \mu \mathrm{M} \mathrm{H} \mathrm{H}_{2} \mathrm{O}_{2}$, and $50 \mu \mathrm{M}$ pyrogallol) was incubated at $25^{\circ} \mathrm{C}$ for $5 \mathrm{~min}$, after which the reaction was stopped by $0.5 \mathrm{~mL} \mathrm{H}_{2} \mathrm{SO}_{4}(5 \%$ $\mathrm{v} / \mathrm{v})$. The absorption rate of the supernatant was read at $420 \mathrm{~nm}$ by spectrophotometry (Lambda 25; Perkin Elmer).

Statistical analysis. Analysis of variance was performed using SAS software (ver. 9.2; SAS Institute, Inc., Cary, NC). Means of samples were compared using Duncan's multiple range test at $1 \%$ and $5 \%$ probability levels.

\section{Results}

Plant growth characteristics. Analysis showed that drought stress, AM fungi, and PGPB treatments, as well as drought stress $\times$ AM fungi and AM fungi $\times$ PGPB, had a significant effect on walnut plant height $(P<$ $0.01)$. G. etunicatum and $G$. mosseae fungi increased plant height significantly under both normal and drought stress conditions. The shortest plant height $(26.70 \mathrm{~cm})$ was observed in the control (without AM fungi treatment) under drought stress conditions (Fig. 1). PGPB alone (Azotobacter chroococcum + Azospirillium lipofrum) improved walnut plant height $(P<0.01)$, but tallest in this experiment was obtained using the combined treatments of G. mosseae + PGPB or $G$. etunicatum + PGPB, which were not significantly different from each other (Fig. 2).

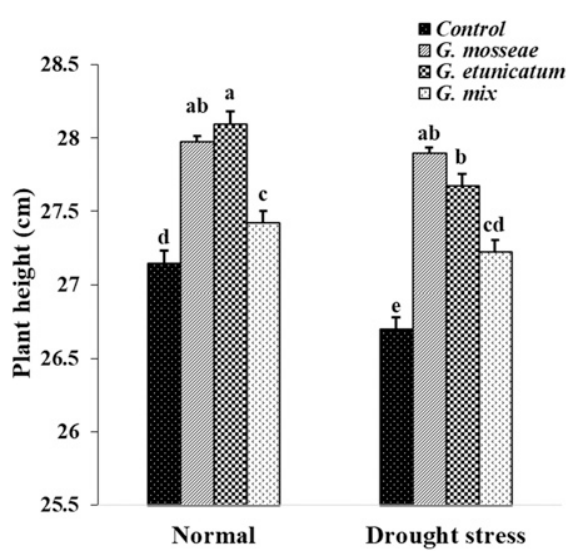

Fig. 1. Effect of arbuscular mycorrhizae fungi on walnut plant height under normal and drought stress conditions.

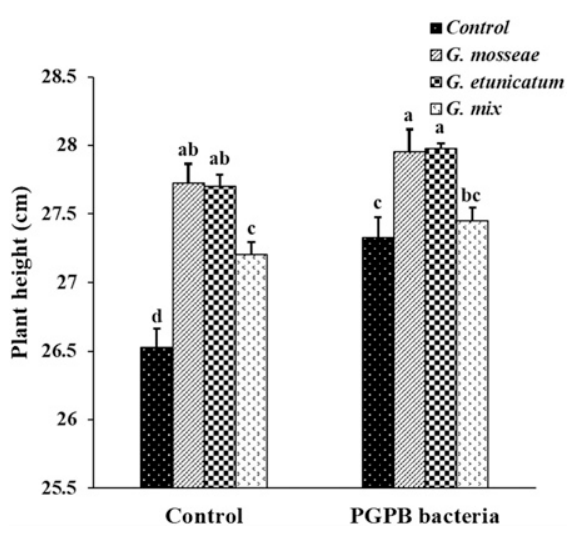

Fig. 2. Effect of arbuscular mycorrhizae fungi and plant growth-promoting bacteria (PGPB) on walnut plant height.

G. etunicatum fungi increased fresh weight under both normal and drought stress conditions. G. mosseae fungus caused greater fresh weight than the G. mix under normal watering, but the G. mix treatment resulted in greater weight of plants than G. mosseae under the drought condition. The lowest fresh weight was observed in the control (no AM fungi) treatment in both normal watering and drought situations (Fig. 3). Fresh weight of plants was also increased by PGPB treatment under normal and drought stress conditions (Fig. 4). The greatest fresh weight of seedlings (360 g) was obtained by simultaneous application of PGPB and $G$. etunicatum fungus (Fig. 5).

The walnut plants treated by G. etunicatum showed the greatest number of leaves under both drought stress and normal conditions. The next greatest number of leaves was observed with the $G$. mosseae treatments, but differences between these two fungi were not significant under either water regime (Fig. 6).

Application of AM fungi and PGPB combined increased number of walnut leaves significantly compared with the control (without AM and PGPB) treatment (Fig. 7). In other words, these symbiotic microorganisms, but especially AM fungi, prevent leaf abscission. 


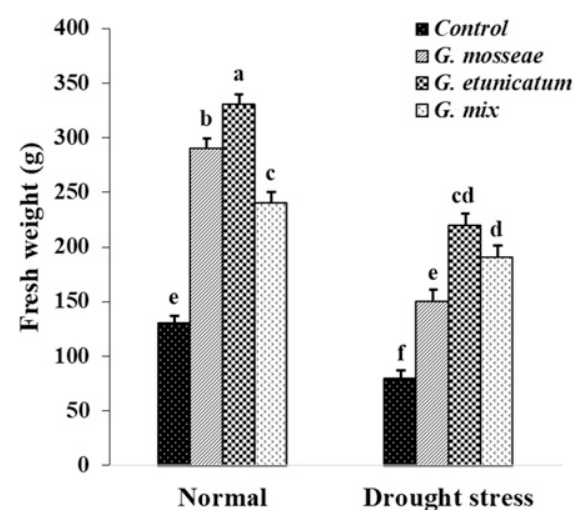

Fig. 3. Effect of arbuscular mycorrhizae fungi on the fresh weight of walnut seedlings under normal and drought stress conditions.

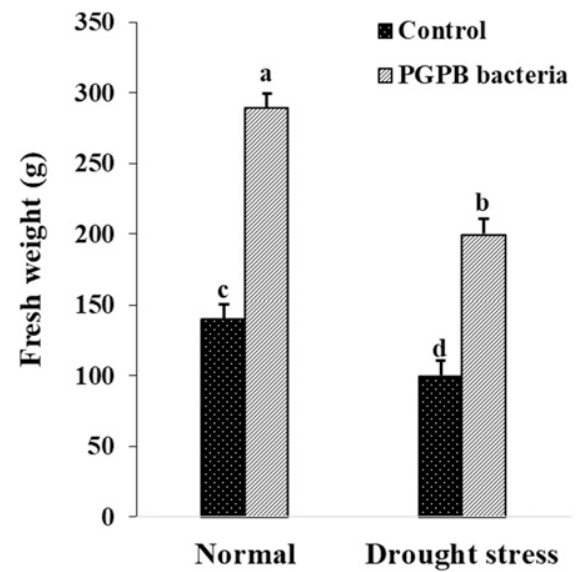

Fig. 4. Effect of plant growth-promoting bacteria (PGPB) on fresh weight of walnut seedlings under normal and drought stress conditions.

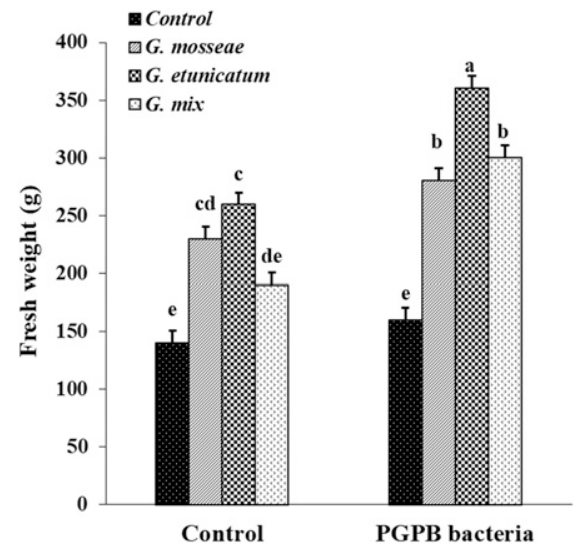

Fig. 5. Effect of arbuscular mycorrhizae fungi and plant growth-promoting bacteria (PGPB) on fresh weight of walnut seedlings.

In general, drought stress caused the walnut leaf abscission. The greatest percentage of leaf abscission was observed in the control treatment (without AM fungi) under drought stress (18 leaves/plant). AM fungi prevented leaf abscission significantly in the drought stress condition, probably as a result

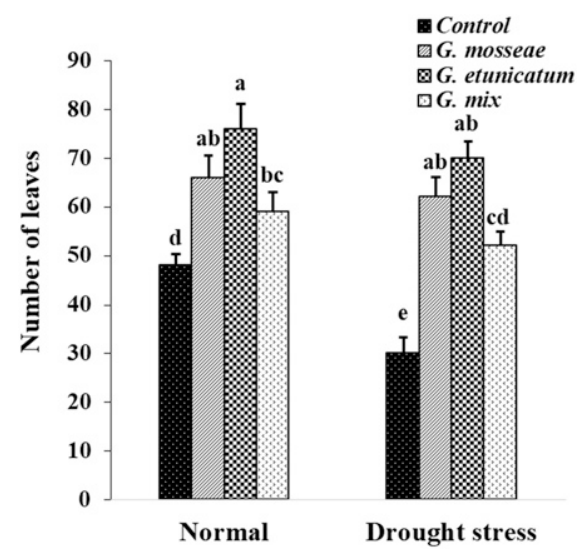

Fig. 6. Effect of arbuscular mycorrhizae fungi on number of walnut leaves under normal and drought stress conditions.

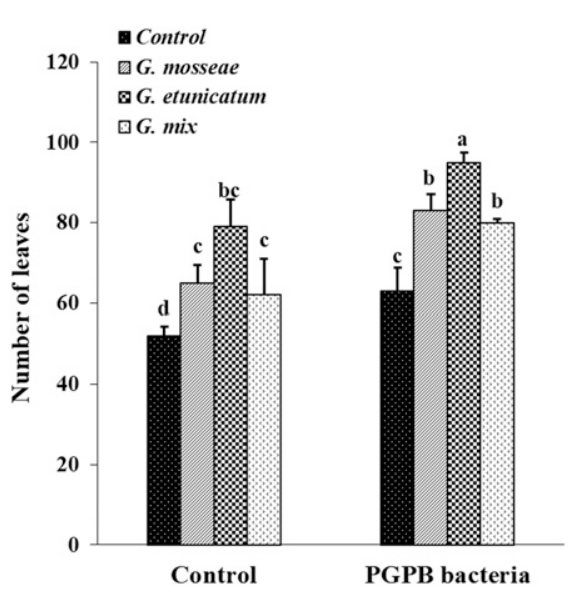

Fig. 7. Effect of arbuscular mycorrhizae fungi and plant growth-promoting bacteria (PGPB) on number of walnut leaves.

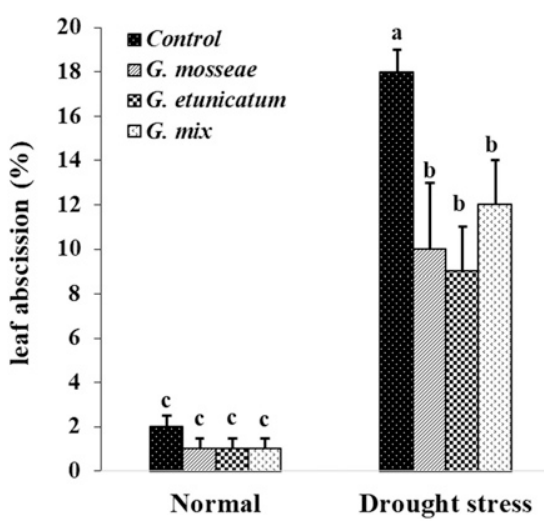

Fig. 8. Effect of arbuscular mycorrhizae fungi on walnut leaf abscission under normal and drought stress conditions.

of increased water absorption by AM fungi (Fig. 8).

The longest root length $(26 \mathrm{~cm})$ was obtained by application of $G$. etunicatum fungus under normal water conditions. In contrast, the shortest root length $(5 \mathrm{~cm})$ was observed in the no-AM treatment (control)

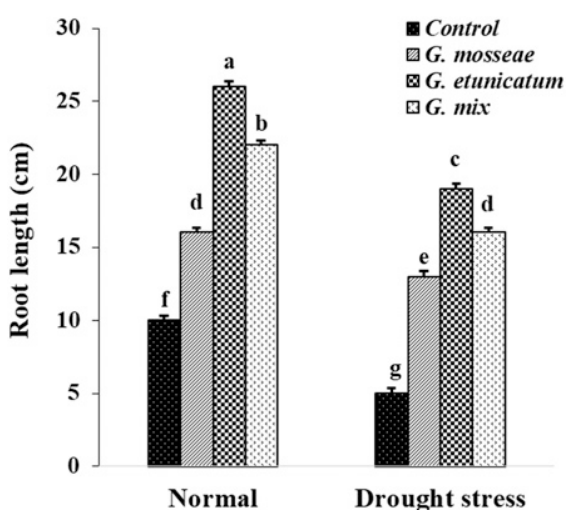

Fig. 9. Effect of arbuscular mycorrhizae fungi on walnut root length under normal and drought stress conditions.

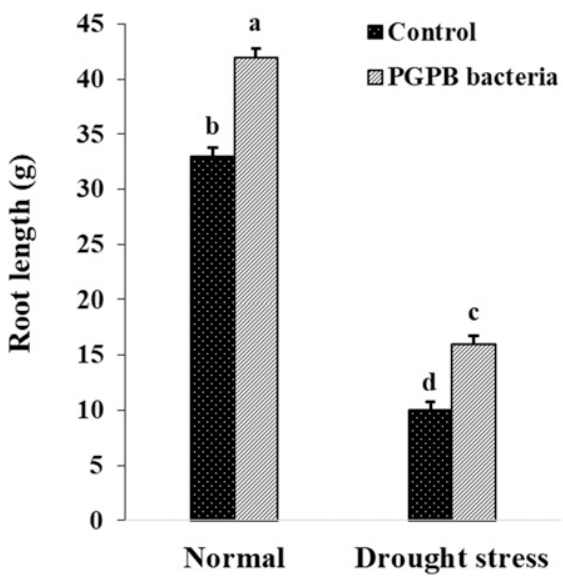

Fig. 10. Effect of plant growth-promoting bacteria (PGPB) on root length of walnut seedlings under normal and drought stress conditions.

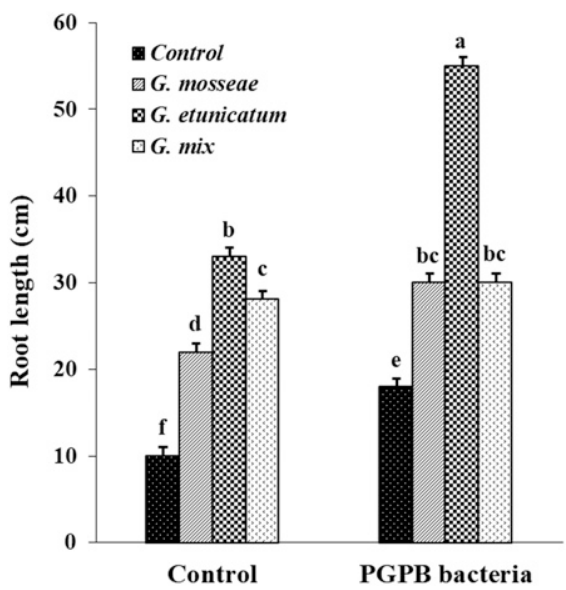

Fig. 11. Effect of arbuscular mycorrhizae fungi and plant growth-promoting bacteria (PGPB) on walnut root length.

under drought stress. In general, the use of AM fungi caused a significant increase in root length under both normal and water stress conditions (Fig. 9).

Application of PGPB (Azotobacter chroococcum + Azospirillium lipofrum) improved 
root growth in both normal and drought stress treatments. There was a significant difference in root length between the control (no PGPB) and PGPB treatment under both conditions (Fig. 10).

The simultaneous application of G. etunicatum mycorrhiza and PGPB further increased root length significantly. Mycorrhiza and symbiotic bacteria combined stimulated the greatest root growth of walnut seedlings. The shortest roots were observed in the control (no AM, no PGPB) treatment (Fig. 11).

Evaluation of total $N, P$, and $Z n$ contents. Drought stress and AM fungi, but not PGPB, affected N, P, and $\mathrm{Zn}$ concentrations of walnut leaves significantly $(P<0.01)$. The interaction of drought stress $\times$ AM fungi also had significant effects on these nutrients $(P<$ $0.05)$. The greatest concentrations of $\mathrm{N}, \mathrm{P}$, and $\mathrm{Zn}$ occurred under normal conditions. Among the AM treatments, use of $G$. etunicatum, especially under normal watering, gave the greatest levels of $\mathrm{P}$ and $\mathrm{Zn}$, whereas the greatest level of $\mathrm{N}$ was observed under normal watering when treated with the $\mathrm{G}$. mix. The lowest concentrations of N, P, and $\mathrm{Zn}$ were observed in leaves of walnut seedlings not treated by AM fungi (Table 1).

Physiologic and biochemical characteristics. AM fungi and PGPB had significant effects on chlorophyll content $(P<0.01)$. In contrast, the effect of drought stress on chlorophyll content was not significant. Figure 12 shows the effect of the AM fungi and PBPB interaction on chlorophyll content. The highest and the lowest chlorophyll contents were observed in the combined G. etunicatum + PGPB treatment and in the control (no AM or PGPB) treatment, respectively. No significant difference was observed between AM fungi treatments when applied either alone or in combination with PGPB (Fig. 12).

Independent effects of AM fungi, PGPB, and drought stress on proline, total soluble sugars, total starch, peroxidase activity $(P<$ $0.01)$, and total phenolic content $(P<0.05)$ were significant. Their bipartite interactions (drought stress $\times$ AM fungi; drought stress $\times$ PGPB and AM fungi $\times$ PGPB) were also significant for these traits. Also, the interaction of drought stress $\times$ PGPB on proline, total soluble sugar, and starch concentrations was not significant. Under drought stress, AM fungi increased proline, total soluble sugar, starch, peroxidase enzyme activity, and total phenolic content significantly. The greatest accumulation of these was observed in the G. etunicatum treatment under drought stress. Walnut seedlings without AM treatment (control) under normal watering had the lowest concentrations of these components. There was no significant difference in proline content among the AM fungi under stress. Also, the amount of peroxidase enzyme activity in the G. etunicatum and G. mix treatments under drought stress condition showed no significant difference (Table 2).

AM fungi in combination with PGPB also increased these biochemical traits significantly relative to the no-AM control (Table 3).

Table 1. Effect of arbuscular mycorrhizae (AM) fungi on leaf nitrogen $(\mathrm{N})$, phosphorus $(\mathrm{P})$, and zinc $(\mathrm{Zn})$ concentrations of walnut under normal and drought stress conditions.

\begin{tabular}{lllcr}
\hline Water condition & AM fungi & $\mathrm{N}(\%)$ & $\mathrm{P}(\mathrm{ppm})$ & \multicolumn{1}{c}{ Zn $(\mathrm{ppm})$} \\
\hline Normal & Control & $4.81 \pm 0.7 \mathrm{~cd}^{\mathrm{z}}$ & $1.52 \pm 0.05 \mathrm{~d}$ & $1.2 \pm 0.03 \mathrm{~d}$ \\
& G. mosseae & $5.63 \pm 0.07 \mathrm{~b}$ & $1.63 \pm 0.05 \mathrm{c}$ & $1.58 \pm 0.02 \mathrm{c}$ \\
& G. etunicatum & $5.40 \pm 0.08 \mathrm{~b}$ & $1.98 \pm 0.04 \mathrm{a}$ & $1.89 \pm 0.04 \mathrm{a}$ \\
& Glomus mix & $6.42 \pm 0.05 \mathrm{a}$ & $1.75 \pm 0.05 \mathrm{~b}$ & $1.68 \pm 0.05 \mathrm{c}$ \\
Drought stress & Control & $4.17 \pm 0.06 \mathrm{~d}$ & $1.48 \pm 0.04 \mathrm{~d}$ & $0.88 \pm 0.03 \mathrm{e}$ \\
& G. mosseae & $4.91 \pm 0.07 \mathrm{c}$ & $1.61 \pm 0.04 \mathrm{c}$ & $1.60 \pm 0.03 \mathrm{c}$ \\
& G. etunicatum & $4.96 \pm 0.07 \mathrm{c}$ & $1.78 \pm 0.03 \mathrm{~b}$ & $1.78 \pm 0.03 \mathrm{~b}$ \\
& Glomus mix & $5.00 \pm 0.06 \mathrm{bc}$ & $1.73 \pm 0.03 \mathrm{~b}$ & $1.65 \pm 0.03 \mathrm{c}$ \\
\hline
\end{tabular}

${ }^{\mathrm{z}}$ Means within each column with the same letter are not significantly different.

Plants treated with both $G$. etunicatum and PGPB had the greatest amount of proline, total soluble sugar, starch, and total phenolic contents and the greatest peroxidase activity. Walnut seedlings without treatment, or treated with PGPB only, had the lowest concentrations and activity. There was little difference in the examined traits between the AM treatments without PGPB (Table 3).

PGPB increased peroxidase enzyme activity under drought stress compared with the control (no PGPB) under the normal condition (Fig. 13). The same result was observed in terms of total phenolic content of walnut leaves (Fig. 14). In the other words, walnut seedlings incubated with PGPB under drought stress showed increased peroxidase activity (6.50 absorbance/min/mg protein) and total phenolic content $(21.10 \mathrm{mg}$ gallic acid equivalent $/ 100 \mathrm{~g}$ ). Walnut seedlings under the normal condition without the PGPB treatment had the lowest amount of peroxidase activity and total phenolic content (Figs. 13 and 14).

\section{Discussion}

Environmental stresses, especially drought, low temperature, and salt, determine geographic distribution of plants and affect plant growth and production dramatically (Rapparini and Penuelas, 2014; Vahdati and Lotfi, 2013). Drought stress is a key environmental constraint on crop production. In recent years, climate change has increased areas affected by drought stress (Alizadeh et al., 2015). Symbiotic microorganisms play a key role in ecosystems. Symbiotic microorganisms such as mycorrhizal fungi or $\mathrm{N}$ fixing bacteria ameliorate water and nutrient absorption and subsequently improve plant performance (Jacoby et al., 2017). Several previous studies have demonstrated that AM fungi and PGPB can alleviate drought stress in a large number of plants (Arzanesh et al., 2011; Augé, 2001). In confirmation of this, our results show that AM fungi, along with PGPB, improve walnut growth characteristics, including plant height, fresh weight, and number of leaves.

Symbiotic microorganisms, especially AM fungi, alleviate drought stress by improving water uptake and transport, and enhance nutrient uptake, especially $\mathrm{P}$ and $\mathrm{N}$ (Augé 2001). One of the main mechanisms regulating plant water uptake under drought stress is by reducing the $\psi_{\mathrm{S}}$ through accu-

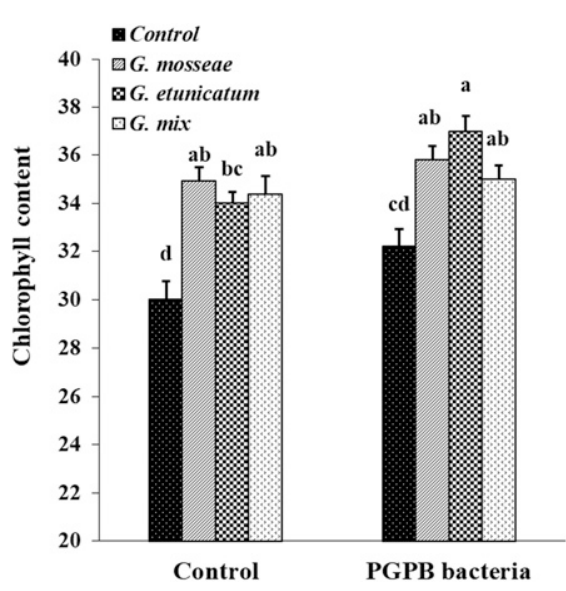

Fig. 12. Effect of arbuscular mycorrhizae fungi and plant growth-promoting bacteria (PGPB) on leaf chlorophyll content of walnut.

mulations of low-molecular weight solutes (Martinez et al., 2004). Under drought stress, AM fungi increase biosynthesis of metabolites - mainly proline and sugarswhich provide osmotic adjustment in plant roots and leaves. In addition, AM fungal hyphae act like additional plant roots, creating an efficient pathway for increased water and nutrient transport and uptake (Rapparini and Penuelas, 2014). In our study, AM fungi and PGPB increased the biosynthesis of some metabolites, including soluble sugar and proline, and contributed to improved walnut plant growth.

Proline is an important amino acid that protects cells from oxidation and acts as a regulator to reduce $\psi_{\mathrm{S}}$ of plant roots and leaves. Drought stress induces a dramatic increase in proline concentration in phloem sap (Lotfi et al., 2009). Deposition of proline increases in roots of water-stressed plants, leading to increased water uptake. Proline then moves to leaves via phloem transport (Girousse et al., 1996). We found that drought stress increased proline accumulation (Lotfi et al., 2010, 2019). Also, AM fungi and PGPB increased proline concentration significantly in walnut leaves, which likely helps walnut plants to cope with drought stress. We also found that AM and PGPB increased total soluble sugar in walnut leaves. Soluble sugars are also important osmotic adjustors in plants (Tan et al., 2006). They act as osmoprotectors, correlated with 
Table 2. Effect of fungi on some biochemical traits of walnut under normal and drought stress conditions.

\begin{tabular}{|c|c|c|c|c|c|c|}
\hline Water condition & AM fungi & $\begin{array}{l}\text { Proline } \\
\left(\mathrm{mg} \cdot \mathrm{g}^{-1}\right)\end{array}$ & $\begin{array}{c}\text { Total soluble } \\
\text { sugar }\left(\mathrm{mg} \cdot \mathrm{g}^{-1} \mathrm{DW}\right)\end{array}$ & $\begin{array}{c}\text { Starch } \\
\text { concn } \\
\left(\mathrm{mg} \cdot \mathrm{g}^{-1} \mathrm{DW}\right)\end{array}$ & $\begin{array}{c}\text { Peroxidase activity } \\
\text { (absorbance/min } / \mathrm{mg} \text { ) }\end{array}$ & $\begin{array}{c}\text { Total phenolic } \\
\text { content } \\
\text { (mg GAE } / 100 \mathrm{~g})\end{array}$ \\
\hline \multirow[t]{3}{*}{ Normal } & Control & $4.87 \pm 1.02 \mathrm{c}^{\mathrm{z}}$ & $5.08 \pm 0.95 \mathrm{~d}$ & $6.74 \pm 0.78 \mathrm{~d}$ & $5.80 \pm 0.52 \mathrm{c}$ & $14.80 \pm 0.72 \mathrm{f}$ \\
\hline & Glomus mosseae & $17.20 \pm 1.42 \mathrm{~b}$ & $9.40 \pm 0.87 \mathrm{c}$ & $12.32 \pm 0.83 \mathrm{c}$ & $6.21 \pm 0.61 \mathrm{c}$ & $16.74 \pm 0.64 \mathrm{ef}$ \\
\hline & Glomus mix & $17.62 \pm 1.10 \mathrm{~b}$ & $10.02 \pm 1.02 \mathrm{c}$ & $11.78 \pm 0.93 \mathrm{c}$ & $6.30 \pm 0.57 \mathrm{c}$ & $18.50 \pm 0.55 \mathrm{de}$ \\
\hline \multirow[t]{2}{*}{ Drought } & Control & $7.50 \pm 1.35 \mathrm{c}$ & $6.33 \pm 0.85 \mathrm{~d}$ & $10.01 \pm 1.21 \mathrm{c}$ & $6.25 \pm 0.38 \mathrm{c}$ & $19.75 \pm 0.72 \mathrm{~cd}$ \\
\hline & G. mosseae & $20.55 \pm 1.11 \mathrm{a}$ & $13.24 \pm 1.01 \mathrm{ab}$ & $19.23 \pm 0.76 b$ & $7.82 \pm 0.52 b$ & $22.05 \pm 0.68 \mathrm{c}$ \\
\hline
\end{tabular}

${ }^{\mathrm{z}}$ Means within each column with the same letter are not significantly different.

$\mathrm{AM}=$ arbuscular mycorrhizae; $\mathrm{DW}=$ dry weight; $\mathrm{GAE}=$ gallic acid equivalent.

Table 3. Effect of arbuscular mycorrhizae (AM) fungi and plant growth-promoting bacteria (PGPB) on some biochemical traits of walnut.

\begin{tabular}{|c|c|c|c|c|c|c|}
\hline PGPB bacteria & AM fungi & $\begin{array}{l}\text { Proline } \\
\left(\mathrm{mg} \cdot \mathrm{g}^{-1}\right)\end{array}$ & $\begin{array}{l}\text { Total soluble sugar } \\
\quad\left(\mathrm{mg} \cdot \mathrm{g}^{-1} \mathrm{DW}\right)\end{array}$ & $\begin{array}{l}\text { Starch concn } \\
\left(\mathrm{mg} \cdot \mathrm{g}^{-1} \mathrm{DW}\right)\end{array}$ & $\begin{array}{l}\text { Peroxidase activity } \\
\text { (absorbance/min/mg) }\end{array}$ & $\begin{array}{c}\text { Total phenolic } \\
\text { content } \\
(\mathrm{mg} \mathrm{GAE} / 100 \mathrm{~g})\end{array}$ \\
\hline \multirow[t]{4}{*}{ Control } & Control & $5.99 \pm 1.57 \mathrm{f}^{z}$ & $4.02 \pm 1.24 \mathrm{c}$ & $5.01 \pm 0.97 \mathrm{~d}$ & $5.37 \pm 0.75 \mathrm{~b}$ & $16.10 \pm 0.43 \mathrm{f}$ \\
\hline & Glomus mosseae & $18.03 \pm 1.31 \mathrm{~d}$ & $11.00 \pm 1.05 \mathrm{~b}$ & $12.72 \pm 0.89 \mathrm{c}$ & $6.58 \pm 0.57 b$ & $18.90 \pm 0.47 \mathrm{e}$ \\
\hline & G. etunicatum & $18.45 \pm 1.42 \mathrm{~b}$ & $14.02 \pm 0.95 \mathrm{a}$ & $15.19 \pm 1.12 \mathrm{c}$ & $7.12 \pm 0.49 \mathrm{~b}$ & $24.80 \pm 0.42 b$ \\
\hline & Glomus mix & $18.06 \pm 1.2 \mathrm{~cd}$ & $10.74 \pm 1.12 \mathrm{~b}$ & $13.60 \pm 1.05 \mathrm{c}$ & $6.86 \pm 0.73 b$ & $21.00 \pm 0.39 \mathrm{~d}$ \\
\hline \multirow[t]{4}{*}{ PGPB bacteria } & Control & $6.25 \pm 1.78 \mathrm{e}$ & $5.10 \pm 1.11 \mathrm{c}$ & $6.83 \pm 0.93 \mathrm{~d}$ & $6.25 \pm 0.73 b$ & $18.44 \pm 0.44 \mathrm{e}$ \\
\hline & G. mosseae & $18.24 \pm 1.34 \mathrm{c}$ & $11.02 \pm 1.01 \mathrm{~b}$ & $16.20 \pm 0.90 \mathrm{bc}$ & $8.42 \pm 0.61 \mathrm{a}$ & $19.85 \pm 0.42 \mathrm{de}$ \\
\hline & G. etunicatum & $18.77 \pm 1.42 \mathrm{a}$ & $15.10 \pm 1.03 \mathrm{a}$ & $22.10 \pm 0.88 \mathrm{a}$ & $9.3 \pm 0.62 \mathrm{a}$ & $26.20 \pm 0.41 \mathrm{a}$ \\
\hline & Glomus mix & $18.18 \pm 1.20 \mathrm{~cd}$ & $10.77 \pm 1.15 \mathrm{~b}$ & $18.70 \pm 1.21 \mathrm{ab}$ & $9.01 \pm 0.57 \mathrm{a}$ & $22.10 \pm 0.39 \mathrm{c}$ \\
\hline
\end{tabular}

${ }^{\mathrm{z}}$ Means within each column with the same letter are not significantly different.

$\mathrm{DW}=$ dry weight; GAE $=$ gallic acid equivalent.

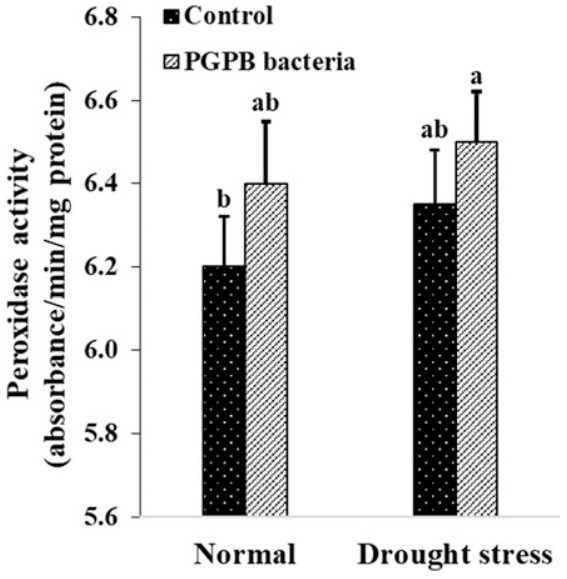

Fig. 13. Effect of plant growth-promoting bacteria (PGPB) on peroxidase activity of walnut leaves under normal and drought stress conditions.

osmotic adjustment and turgor maintenance, and stabilize protein and membranes (Ingram and Bartels, 1996).

Reactive oxygen species are induced and accumulate under drought stress (Carvalho, 2008). Enhancement of antioxidant enzyme activity is a mechanism for reducing the negative effects of drought stress by reducing oxidative stress (Lotfi et al., 2019). Zhu et al. (2011) reported that peroxidase activity in leaves of maize plants inoculated with AM fungi was greater than in nonmycorrhizal plants. Our results also demonstrate that AM fungi reduce drought and oxidative stress by increasing peroxidase enzyme activity (Wu and Zou, 2009).

Symbiotic microorganisms can enhance micronutrient uptake directly (Ramos et al.,

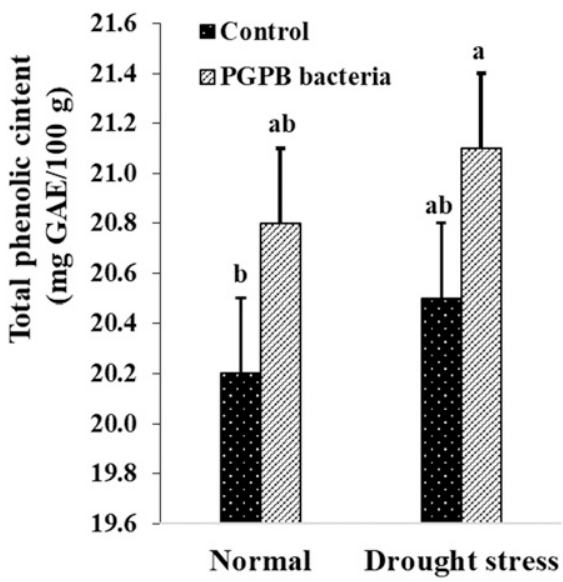

Fig. 14. Effect of plant growth-promoting bacteria (PGPB) on total phenolic content of walnut leaves under normal and drought stress conditions. $\mathrm{GAE}=$ gallic acid equivalent.

2002). Our results show that AM fungi increased nutrient absorption, especially $\mathrm{N}$ and P. Mycorrhizae are, in most cases, not essential for plant life, especially if soil nutrient levels are high, but mycorrhizae are usually present and beneficial. When nutrient supply is poor, growth improvement resulting from the addition of mycorrhizae can be substantial. Mycorrhizae are especially important for the absorption of $\mathrm{P}$. In addition to promoting nutrient uptake, mycorrhizae help protect roots from disease and can assist in water uptake. Enhancement of nutrient uptake by AM fungi and PGPB is a fundamental mechanism in ameliorating the adverse effects of drought stress on plant growth (Rapparini and Penuelas, 2014).

\section{Conclusion}

In conclusion, our results show that application of AM fungi, especially $G$. etunicatum, and PGPB can improve growth and nutrient acquisition of walnut plants under drought stress. AM and PGPB increased some osmotic compounds significantly, including proline, total carbohydrates, and soluble sugar compounds, which probably increased water absorption under drought stress. In addition, AM fungi increased root growth, which can increase water absorption. AM also increased the absorption of $\mathrm{N}, \mathrm{P}$, and $\mathrm{Zn}$ significantly under drought stress conditions. In conclusion, we suggest inoculation of walnut plants with AM fungi (especially G. etunicatum) and PGPB before planting in an orchard, particularly in areas likely subject to drought stress, to improve walnut plant growth and to sustain crop production.

\section{Literature Cited}

Alizadeh, V., V. Shokri, A. Soltani, and M.A. Yousefi. 2015. Effects of climate change and drought-stress on plant physiology. Intl. J. Adv. Biol. Biomed. Res. 3(1):38-42.

Arzanesh, M.H., H.A. Alikhani, K. Khavazi, H.A. Rahimian, and M. Miransari. 2011. Wheat (Triticum aestivum L.) growth enhancement by Azospirillum sp. under drought stress. World J. Microbiol. Biotechnol. 27(2):197-205.

Augé, R.M. 2001. Water relations, drought and vesicular-arbuscular mycorrhizal symbiosis. Mycorrhiza 11:3-42.

Barzana, G., R. Aroca, J.A. Paz, F. Chaumont, M.C. Martinez-Ballesta, M. Carvajal, and J.M. Ruiz-Lozano. 2012. Arbuscular mycorrhizal symbiosis increases relative apoplastic water flow in roots of the host plant under both 
well-watered and drought stress conditions. Ann. Bot. 109(5):1009-1017.

Basu, S., V. Ramegowda, A. Kumar, and A. Pereira. 2016. Plant adaptation to drought stress. F1000 Res. 5:1-10.

Bates, L.S., R.P. Waldron, and I.D. Teare. 1973. Rapid determination of free proline for water stress studies. Plant Soil 39(1):205-208.

Blainski, A., G.C. Lopes, and J.C.P. De Mello. 2013. Application and analysis of the folin ciocalteu method for the determination of the total phenolic content from Limonium brasiliense L. Molecules 18(6):6852-6865.

Bradstreet, R.B. 1954. Kjeldahl method for organic nitrogen. Anal. Chem. 26(1):185-187.

Carvalho, M.H.C. 2008. Drought stress and reactive oxygen species: Production, scavenging and signaling. Plant Signal. Behav. 3(3):156165.

Chow, P.S. and S.M. Landhausser. 2004. A method for routine measurements of total sugar and starch content in woody plant tissues. Tree Physiol. 24(10):1129-1136.

Evelin, H., R. Kapoor, and B. Giri. 2009. Arbuscular mycorrhizal fungi in alleviation of salt stress: A review. Ann. Bot. 104(7):1263-1280.

Farooq, M., A. Wahid, N. Kobayashi, D. Fujita, and S.M.A. Basra. 2009. Plant drought stress: Effects, mechanisms and management. Agron. Sustain. Dev. 29(1):185-212.

Food and Agriculture Organization. 2017. FAOSTAT trade. http://www.fao.org/faostat/en/ \#data/TP.

García-Tejero, I., V.H. Durán-Zuazo, J. ArriagaSevilla, and J.L. Muriel-Fernández. 2012. Impact of water stress on citrus yield. Agron. Sustain. Dev. 32(3):651-659.

Girousse, C., R. Bournoville, and J.L. Bonnemain. 1996. Water deficit-induced changes in concentrations in proline and some other amino acids in the phloem sap of alfalfa. Plant Physiol. 111:109-113.

Habte, M., S.C. Miyasaka, and D.T. Matsuyama. 2001. Arbuscular mycorrhiza fungi improve early forest-tree establishment, p. 644-645. In: W.J. Horst, M.K. Schenk, A. Burkert, N. Claassen, H. Flessa, W.B. Frommer, H. Goldbach, H.W. Olfs, V. Romheld, B. Sattelmacher, U. Schmidhalter, S. Schubert, N. von Wirén, and L. Wittenmayer (eds.). Plant nutrition: Food security and sustainability of agroecosystems through basic and applied research. Springer, Dordrecht, Netherlands.

Ingram, J. and D. Bartels. 1996. The molecular basis of dehydration tolerance in plants. Annu. Rev. Plant Biol. 47(1):377-403

Jacoby, R., M. Peukert, A. Succurro, A. Koprivova, and S. Kopriva. 2017. The role of soil microorganisms in plant mineral nutrition: Current knowledge and future directions. Front. Plant Sci. 8:1617.

Kar, M. and D. Mishra. 1976. Catalase, peroxidase, and polyphenoloxidase activities during rice leaf senescence. Plant Physiol. 57(2):315-319.

Kubikova, E., L.M. Jennifer, H.O. Bonnie, D.M. Michael, and M.R. Augé. 2001. Mycorrhizal impact on osmotic adjustment in Ocimum basilicum during a lethal drying episode. J. Plant Physiol. 158(9):1227-1230.

Lotfi, N., A. Soleimani, K. Vahdati, and R. Çakmakç1. 2019. Comprehensive biochemical insights into the seed germination of walnut under drought stress. Scientia Hort. 250:329343.

Lotfi, N., K. Vahdati, B. Kholdebarin, and R. Amiri. 2009. Soluble sugars and proline accumulation play a role as effective indices for drought tolerant screening in Persian walnut (Juglans regia L.) during germination. Fruits 65(2):1-14.

Lotfi, N., K. Vahdati, B. Kholdebarin, and R. Amiri. 2010. Drought-induced accumulation of sugars and proline in radicle and plumule of tolerant walnut varieties during germination phase. Acta Hort. 861:289-296.

Manjunath, A. and M. Habte. 1988. Development of vesicular-arbuscular mycorrhizal infection and the uptake of immobile nutrients in Leucaena leucocephala. Plant Soil 106(1):97-103.

Martinez, J.P., S. Lutts, A. Schanck, M. Bajji, and J.M. Kinet. 2004. Is osmotic adjustment required for water stress resistance in the Mediterranean shrub Atriplex halimus L? J. Plant Physiol. 161(9):1041-1051.

Masson, P., T. Dalix, and S. Bussière. 2010. Determination of major and trace elements in plant samples by inductively coupled plasmamass spectrometry. Commun. Soil Sci. Plant Anal. 41(3):231-243.

Pickles, B.J. and S.W. Simard. 2017. Mycorrhizal networks and forest resilience to drought, $p$ 319-339. In: N.C. Johnson, C. Gehring, and J Jansa (eds.). Mycorrhizal mediation of soilfertility, structure, and carbon storage. Elsevier, Amsterdam.

Ramos, H.J., L.D. Roncato-Maccari, E.M. Souza, J.R. Soares-Ramos, M. Hungria, and F.O. Pedrosa. 2002. Monitoring Azospirillum-wheat interactions using the $g f p$ and gusA genes constitutively expressed from a new broadhost range vector. J. Biotechnol. 97(3):243252.

Rapparini, F. and J. Penuelas. 2014. Mycorrhizal fungi to alleviate drought stress on plant growth, p. 21-42. In: M. Miransari (ed.). Use of microbes for the alleviation of soil stresses. Vol. 1. Springer, New York, NY.

Romero-Perdomo, F., J. Abril, M. Camelo, A. Moreno-Galván, I. Pastrana, D. Rojas-Tapias, and R. Bonilla. 2017. Azotobacter chroococcum as a potentially useful bacterial biofertilizer for cotton (Gossypium hirsutum): Effect in reducing $\mathrm{N}$ fertilization. Rev. Argent. Microbiol. 49(4):377-383.

Sahebi, M., M.M. Hanafi, M.Y. Rafii, T.M.M Mahmud, P. Azizi, M. Osman, R. Abiri, S Taheri, N. Kalhori, M. Shabanimofrad, and G. Miah. 2018. Improvement of drought tolerance in rice (Oryza sativa L.): Genetics, genomic tools, and the WRKY gene family. Biomed Res. Intl. 2018:1-20.

Tan, Y., Z. Liang, H. Shao, and F. Du. 2006. Effect of water deficits on the activity of antioxidative enzymes and osmoregulation among three different genotypes of Radix astragali at seeding stage. Colloids Surf. B Biointerfaces 49(1):60-65.

Vahdati, K., D. Hassani, R. Rezaee, M.J. Sayadi, and S.S. Khorami. 2014. Following walnut footprints (Juglans regia L.): Cultivation and culture, folklore and history, traditions and uses, p. 187-201. In: Walnut footprint in Iran. Scripta Hort.

Vahdati, K. and N. Lotfi. 2013. Abiotic stress tolerance in plants with emphasizing on drought and salinity stresses in walnut, $p$. 307-365. In: K. Vahdati and C. Leslie (eds.). Abiotic stress: Plant responses and applications in agriculture. In Tech, Rijeka, Croatia.

Vahdati, K., N. Lotfi, B. Kholdebarin, D. Hassani, R. Amiri, M.R. Mozaffari, and C. Leslie. 2009. Screening for drought-tolerant genotypes of Persian walnuts (Juglans regia L.) during seed germination. HortScience 44:1815-1819.

Viscardi, S., V. Ventorino, P. Duran, A. Maggio, S. De Pascale, M.L. Mora, and O. Pepe. 2016. Assessment of plant growth promoting activities and abiotic stress tolerance of Azotobacter chroococcum strains for a potential use in sustainable agriculture. J. Soil Sci. Plant Nutr. 16(3):848-863.

Wu, S.C., Z.H. Cao, Z.G. Li, K.C. Cheung, and M.H. Wong. 2005. Effects of biofertilizer containing $\mathrm{N}$-fixer, $\mathrm{P}$ and $\mathrm{K}$ solubilizers and AM fungi on maize growth: A greenhouse trial. Geoderma 125(1-2):155-166.

Wu, Q.S., X.H. He, Y.N. Zou, C.Y. Liu, J. Xiao, and Y. Li. 2012. Arbuscular mycorrhizas alter root system architecture of Citrus tangerine through regulating metabolism of endogenous polyamines. Plant Growth Regulat. 68(1):2735.

Wu, Q.S., A.K. Srivastava, and Y.N. Zou. 2013. AMF-induced tolerance to drought stress in citrus: A review. Scientia Hort. 164:77-87.

Wu, Q.S. and Y.N. Zou. 2009. Mycorrhiza has a direct effect on reactive oxygen metabolism of drought-stressed citrus. Plant Soil Environ. 55:436-442.

Yang, S.J., Z.L. Zhang, Y.X. Xue, Z.F. Zhang, and S.Y. Shi. 2014. Arbuscular mycorrhizal fungi increase salt tolerance of apple seedlings. Bot. Stud. 55(1):70.

Yooyongwech, S., N. Phaukinsang, S. Cha-um, and K. Supaibulwatana. 2013. Arbuscular mycorrhiza improved growth performance in Macadamia tetraphylla L. grown under water deficit stress involves soluble sugar and proline accumulation. Plant Growth Regulat. 69(3):285293.

Zhu, X., F. Song, and S. Liu. 2011. Arbuscular mycorrhiza impacts on drought stress of maize plants by lipid peroxidation, proline content and activity of antioxidant system. J. Food Agr. Environ. 9(2):583-587.

Zia-ur-Rehman, M., A . Naeem, H. Khalid, M. Rizwan, S. Ali, and M. Azhar. 2018. Responses of plants to iron oxide nanoparticles, p. 221238. In: D.K. Tripathi, P. Ahmad, S. Sharma, D.K. Chauhan, and N.K. Dubey (eds.). Nanomaterials in plants, algae, and microorganisms. Academic Press. 